\title{
NOVÉ PUBLIKACE
}

\author{
Laura Coltofean-Arizancu - Bisserka Gaydarska - Uroš Matić (eds.): Gender stereotypes \\ in archaeology: a short reflection in image and text. Sidestone Press, Leiden 2021. ISBN \\ 9789464260250. 64 str.
}

Nizozemské nakladatelství Sidestone Press, zaměřující se na akademické publikace z oborů archeologie a antropologie, vydalo nedávno brožuru týkající se genderových stereotypů v archeologii. Jejím základním cílem není být další vědeckou monografií zabývající se genderovou archeologií, nýbrž krátce informovat a kriticky reagovat na základní genderové stereotypy vyskytující se běžně $\mathrm{v}$ archeologických interpretacích i odborné praxi. Celá iniciativa vznikla z nápadu egyptologa Uroše Matiće a byla realizována díky snaze komunity Archaeology and Gender in Europe (AGE) při European Association of Archaeologists (EAA). Cílem této oficiální vědecké komunity bylo a stále je mít archeologii různorodou, inkluzivní, rovnoprávnou a bezpečnou. Publikace obsahuje 24 krátkých esejů (250 slov) doplněných ilustracemi srbského umělce Nikoly Radosavljeviče, které diskutované stereotypy zobrazují. Editorky a editor hned v úvodu prozrazují to, co by si čtenáři a čtenářky měli/-y pro přečtení odnést: „Nedomnívejme se nic o minulosti ani o lidech, kteř́ ji studují.“

Eseje, které vysvětlují konkrétní genderové stereotypy, tvoří v knize i jakési tematické bloky. V prvním se několik autorů a autorek zaměřuje na naše stereotypní myšlení o ženách a mužích v minulosti i současnosti. Bettina Arnold hned v úvodním eseji ukazuje, jak se naše myšlení o tom, že muži byli lovci a ženy se zabývaly jen starostí o domácnost, přenáší i do současné praxe archeologie, kde muži „lovi““ data při terénním výzkumu a ženy následně tato data „vaří“ laboratoři. Někteří se nad tím možná jen pousmějí, mnozí z nás se však s takovou dělbou práce při archeologickém výzkumu setkali, a lze se také ptát, kde vězí kořeny právě takové dělby práce na některých českých archeologických institucích. Důležitým aspektem všech lidských společností je péče o děti, staré či nemocné. Marga Sánchez Romero a Katharina Rebay-Salisbury ukazují, že, jak dnes, tak v minulosti, o lidi, kteří péči potřebují, pečuje celá jejich komunita, a ne pouze ženy. V archeologii je tento stereotyp spojován s (falešnou) představou, že tyto činnosti nevyžadují žádné technologie, znalosti ani zkušenosti. Právě ty jsou stereotypně spojovány s muži.

S rozvojem využití aDNA v archeologii se důležitým tématem stává rodina. Julia K. Koch ve dvou esejích připomíná, že často ve svých interpretacích přenášíme současný model rodiny (matka, otec, děti) do minulosti a snažíme se tam podobné struktury najít. Často si však neuvědomujeme, že rodina nemá jen svou biologickou stránku, ale jejím významným aspektem dnes i v minulosti je její sociální konstrukce. Lidé se s mnohými svými biologickými př́ibuznými vůbec nesetkávají a mnohé nepříbuzné naopak do své rodiny skrze různé sociální mechanismy přijímají. Naše oborová krátkozrakost vyplouvá na povrch i v situacích, kdy u vícenásobných pohřbů mnohdy automaticky předpokládáme prríbuznost nebo vztah daných lidí. Koch v tomto př́ípadě vyzdvihuje důležitost kombinace kritického myšlení a moderních analytických metod, které vedou k získávání faktů.

Následují eseje (z pera Kathariny Rebay-Salisbury, Sandry Montón-Subías, Pamely L. Geller a Alice B. Kehoe) se zaměřily na pochopení termínu gender. Hned v prvním jsou jednoduše vysvětleny rozdíly mezi pohlavím a genderem, který by se do češtiny snad mohl přeložit jako rod. RebaySalisbury připomíná, že často jsou tyto termíny zaměňovány nebo naprosto nepochopeny. Připomíná, že biologické pohlaví (anglicky sex) je určováno pro minulé populace na základě sexuálního dimorfismu na skeletu nebo aDNA, kdežto gender neboli rod, je sociálně konstruovaný. Genderová role může být jedinci připsána ostatními po porodu, naučená během dospívání a lidé ji také mohou měnit v průběhu života, protože se nejedná o neměnnou společenskou kategorii. Autorka svým esejem také připomíná, že gender není striktně binární koncept a prolíná se s dalšími sociálními kategoriemi jako věk nebo sociální status. Sandra Montón-Subiás k tomu svým esejem dodává, že systém pohlaví i genderu nejsou a nebyly binární, natožpak přirozené. Co znamená být ženou nebo mužem 
je produktem složitých sociálních a kulturních procesů, které se navíc mohou odehrávat v prostředí společenské nerovnosti. V minulosti, stejně jako dnes, byly a jsou genderové role mnohem rozmanitější, a mnoho lidí tak mohlo úplně odmítat binární dělení na muže a ženy, nebo biologicky jednoduše nezapadlo ani do jedné z těchto kategorií. Genderové kategorie prostě nemůžeme chápat heteronormativně. Pokud tak však v našem výzkumu činíme a přenášíme současné mainstreamové (a zároveň nepoučené) vidění genderových rolí do minulosti, dopouštíme se zásadní metodologické chyby reprodukující moderní strukturální nerovnosti ve společnosti, píše autorka.

Předposlední oddíl esejů se zaměřuje na samotnou praxi genderové archeologie. Uroš Matić vyvrací ve svém eseji stereotyp o tom, že gender zkoumá genderová archeologie jako ideologii. Matić argumentuje, že genderová ideologie (příp. genderová, feministická a gay lobby) je populistický termín využívaný v extrémně pravicovém prostředí pro označení myšlenek a konceptů feministické teorie. Feminismus propagující společenskou rovnost a svobodu je podle extrémní pravice ohrožením rodiny, morálky i národa, a právě proto jsou koncepty feministické teorie onálepkovány slovem ideologie. Ideologie pak samozřejmě musí být jen lží oproti stavu, kterým lidstvo obdařila př́roda, či dokonce Bůh, vysvětluje myšlenkové pochody populistické extrémní pravice Matić. Následující eseje Rachel Pope a Doris Gutschmiedl-Schümann demonstrují, koho se genderová archeologie týká. Argumentují, že genderovými kategoriemi se ve svém výzkumu zabývají v podstatě všichni archeologové a archeoložky, jen někteří z nich méně vědomě a bez teoretické reflexe. Genderová archeologie se liší právě sebereflexí a snahou vyvarovat se domněnek o fungování společnosti založených na zdravém (či v ČR tolik oblíbeném selském) rozumu. Genderová archeologie se tak, jako jedna z mála odnoží naší vědní disciplíny, zabývá jak lidmi v minulosti, tak v současnosti. Od 70. let 20. století, kdy se do archeologie (zejm. v USA) dostávají feministické myšlenky, se také výrazně rozšîríl záběr genderové archeologie. Gutschmiedl-Schümann zmiňuje, že dnes se genderová archeologie zabývá celou šiří sociálních skupin - ženami i muži (queer, trans, cis), dětmi, starými lidmi, lidmi s jinou než bílou pletí nebo lidmi s hendikepem. Všechny tyto kategorie pak mohly, ale i nemusely hrát v minulosti nějakou roli. Nils Müller-Scheeßel pak k tomu dodává, že zkoumání témat genderové archeologie je nadmíru důležité i pro současnou společnost. Umožňuje nám to totiž vidět genderové problémy dneška.

Uroš Matić a Bo Jensen obracejí v následujících esejích svoji pozornost ke queer archeologii. Matić rozporuje stereotyp o tom, že stejnopohlavní sexuální praktiky jsou jen moderním výmyslem či úchylkou. Argumentuje tím, že historie i archeologie poskytují dostatek důkazů o tom, že lidé stejného pohlaví spolu měli v minulosti sexuální i partnerské vztahy, a pokud někdo tvrdí opak, je ovlivněn homofobní propagandou státních či náboženských institucí, které se snaží omezovat neheterosexuální chování. Jensen doplňuje, že queer archeologie netkví v tom, že by si queer archeologové a archeoložky představovali queer lidi v minulosti, ale spočívá v uvědomění si, že skutečné životy jakékoliv skupiny (muži, ženy, děti, sexuální, náboženské, etnické majority nebo minority) jsou historicky a kulturně podmíněny. Queer archeologie dále podle Jensena zpochybňuje, podobně jako v současnosti queer lidé, heteronormativní status quo.

Poslední dva eseje (Maria Mina, Laura Coltofean-Arizancu, Bisserka Gaydarska) se zaměřují na genderově podmíněné pracovní podmínky v archeologii. První se zaměřuje na podmínky, jakým musí čelit archeoložky. Autorka připomíná, že v našem oboru je rozšířená domněnka o tom, že ženy mají v archeologii stejné př́ležitosti jako muži a že kariérní úspěch je otevřen všem schopným a talentovaným lidem. K tomu však dodává, že tato falešná domněnka je produktem neoliberálního myšlení a hluboce zakořeněných strukturálních mocenských vztahů. Svou argumentaci podporuje odkazy na nedávné průzkumy uvnitř archeologické komunity v USA a ve Velké Británii. V posledním eseji se autorky-editorky zaměřují na sexuální obtěžování, útoky, šikanu a zastrašování a snaží se vyvrátit častý mýtus, že se tyto (patologické) jevy archeologii vyhýbají. Jistě nepostihují všechny a některá archeologická pracoviště se jim snaží aktivně zabraňovat, i tak se čas od času objeví až děsivé př́klady zacházení s kolegy/-němi a studenty/-tkami. Ty jsou dobře zobrazeny na ilustraci k eseji, kde se objevuje motiv nástěnky s výroky obětí či agresorů (např. „Každý to věděl, ale báli jsme se nějak reagovat kvůli kariére. "; ,Samozřejmě tím nemyslíme, že je gay, je to jen vtip a je fakt vtipný, že? ?"; „Pokud tohle neuděláš, zapomeň na archeologii!“; překlad J. K.). 
Jak tedy tuto brožuru hodnotit? Hned na začátku je možná pro české (bohužel i akademické) prostředí nutné vyvrátit stereotyp o tom, že podobný publikační počin není dílem vědců a vědkyň, nýbrž aktivistů/-tek. Autoři a autorky patří ke známým vědeckým postavám evropské a severoamerické archeologie, publikujícím v předních akademických nakladatelstvích, př́íp. získávajícím finance na své výzkumné projekty skrze nejprestižnější agentury (European Research Council ad.). $\mathrm{O}$ vědecké vyspělosti pisatelů a pisatelek svědčí i formát esejủ. Vždy se jedná o argumentační esej, do jehož délky (250 slov) nebylo jistě jednoduché dostat všechny důležité argumenty pro vyvrácení příslušných stereotypů. Kladně hodnotím i podařené ilustrace.

Osobně si kladu otázku, jaký dopad by tato úderná brožura mohla mít, a to zejména na českou archeologii. Té se totiž genderové problémy, stejně jako v jiných zemích, nevyhýbají. Během studií mnozí z nás zaslechli či zažili třídění terénních brigádníků a brigádnic na práci podle jejich vnímané genderové role, a ne podle toho, jak je kdo schopen např. uvést kolečko s hlínou. V muzeích či ve vědeckých konferenčních příspěvcích mnohdy zahlédneme rekonstrukční ilustrace, kde jsou ženy zobrazovány jako polonahé bezduché sexuální objekty, které často nedělají nic, kdežto muži bojují, loví, či očividně ovládají alespoň nějakou zásadní technologii. Postavení archeoložek v ČR dobře ilustruje i fakt, že jedinou a poslední profesorkou archeologie byla Růžena Vacková. Ta byla jmenována v roce 1947, avšak její kariéru zhatil komunistický převrat. Během zbytku 20. století se v oborech archeologie nebo klasická archeologie habilitovaly pouze dvě ženy působící v ČR (Eliška Kazdová, Iva Ondřejová). V rámci Československa je nutné zmínit profesorky Márii Novotnou a Tatianu Štefanovičovou. V posledních letech několik habilitovaných archeoložek přibylo, profesorky archeologie jsou však v ČR stále v nedohlednu. Ženy tvoří i minority v redakčních radách předních českých archeologických časopisů a např. Památky archeologické měly donedávna čistě mužskou redakční radu. Postavení žen, či jiných skupin, které mohou trpět strukturálními překážkami ve studiu či kariérním postupu, musíme brát vážně, ostatně i z ČR známe př́íklad rafinované a zákeřné šikany na pracovišti (tzv. mobbingu). Obětí byla před několika lety přední archeoložka a antropoložka Martina Galetová, které tehdejš́ ředitel Moravského zemského muzea odmítl podepsat smlouvu o grantu na její vědecký projekt, a dokonce se s ní snažil ukončit pracovní poměr. Česká archeologická komunita se tehdy velmi dobře aktivizovala, identifikovala toto patologické chování na pracovišti a za Martinu Galetovou se postavila. Tento př́pad byl jasný a čitelný, nicméně v české archeologii existují i mnohem subtilnější, někdy až bizarní myšlenky týkající se žen. Např. Vladimír Podborský ve svém Úvodu do studia archeologie uvádí, že ,ženy se od počátku dějin prosazovaly predevš́ím rečí, mluvením“, načež doplňuje, že ,žena prý dokáže používat svou reč i jako zbraň proti mǔ̌i““ (Podborský 2012, 19). Má takové smýšlení místo v knize, kterou vysokoškolský profesor zamýšlel pro své studenty a studentky?

Doufejme tedy, že recenzovaná brožura pronikne brzy i mezi české archeology a archeoložky, zejména mezi ty studující, a zlepší povědomí o genderové archeologii. Jednak v kariérní či studijní sféře, aby nastupující generace uměly lépe rozpoznat nepřijatelné chování ze strany nadřízených, školitelů a školitelek a nestali/-y se obětmi genderově motivovaného mobbingu, homofobní šikany, sexuálního obtěžování či dokonce agrese. A jednak by tato publikace mohla naklonit genderové archeologii více studujících, které by zajímalo poznávat minulý život běžně marginalizovaných skupin. Genderová archeologie na vědecké úrovni se totiž v ČR pěstuje jen okrajově (v poslední době např. Remišová Věšínová 2017; Doležalová 2013). Zvláštní pozici žen v české archeologii ostatně ilustruje i fakt, že v monotematickém čísle Ženy v archeologii revue Dějiny a současnost (3/2017) píší o ženách pouze muži.

Obecnou důležitost celého publikačního počinu podtrhuje i to, že byl financován tzv. zdola. Kniha měla svoji vlastní fundraisingovou kampaň a potřebná částka byla vybrána během pouhých šesti dní. Jak lze však nalézt na obálce, její vydání podpořily i přední západoevropské univerzity s archeologickými pracovišti (Christian-Albrechts-Universität zu Kiel, Universiteit Leiden, University College Dublin, Bournemouth University). Nezbývá než doufat, že dostatečnému šíření této zdařilé a důležité knihy napomůže i možnost stáhnutí zdarma přímo z webu nakladatelství Sidestone Press (https://www.sidestone.com/books/gender-stereotypes-in-archaeology). 


\section{Literatura}

Doležalová, K. 2013: První ženy moravské archeologie. Studia archaeologica Brunensia 18, 63-78.

Podborský, V. 2012: Úvod do studia archeologie. Brno: Masarykova univerzita.

Remišová Věšinová, K. 2017: Gender a pravěká společnost. Præhistorica. Praha: Univerzita Karlova, Nakladatelství Karolinum.

Jiří Škabrada a kol.: Lidová architektura v jižních Čechách. Společnost pro obnovu vesnice a malého města, Brno 2021. 726 str. + 1 CD.

Syntéza autorského kolektivu vedeného Jiřím Škabradou je adaptací pětatřicet let staré monografie o téže problematice ze stejné oblasti. První kniha, jejíž rukopis byl dokončen v roce 1983, vznikla za spolupráce dvou architektů (Voděra - Škabrada 1986). Byt je jako její hlavní autor uveden Svatopluk Voděra, o deset let mladší Jiří Škabrada, který v roce vydání knihy oslavil čtyřicátiny, se projevil jako metodologicky vyzrálejší a invenčnější osobnost. V několika kapitolách předestřel úplně nový způsob myšlení o lidové architektuře, zacílený na vyhledávání typologických zákonitostí v genezi vnitřních dispozic domů i dispozic usedlostí jako celků. Průkopnický byl i jeho důraz kladený na poznávání konstrukcí.

Škabradova optika ostře kontrastovala s tradicí etnografického bádání, věnujícího pozornost především vnějškovým znakům vesnických domů. V jejím hledáčku se ocitaly bud’ stavby na první pohled archaicky prosté, přitahující zájem např. malebnými doškovými stř̌echami, nebo naopak okázalé, s nápadnými zlidovělými ozvuky barokního tvarosloví. Ani mladý Jiř̌i Škabrada neztrácel ze zřetele estetickou stránku rolnických usedlostí, vždy jí ale předřazoval jiné, skryté aspekty, které však dovolují postihnout hlavní vývojová stádia vertikální a horizontální struktury domů, potažmo umožňují absolutně (byt třeba v širokých intervalech) datovat konkrétní stavby.

Výše naznačená badatelská perspektiva v nové knize výrazně zesílila. Změny ale zčásti mají i vynucený důvod, protože Svatopluk Voděra zemřel v roce 2001. Jeho texty se v nové knize neuplatňují, na rozdíl od hojných kreseb. Problematika, které se věnoval, ale není vynechána. Zčásti ji do svého výkladu integroval Jiří Škabrada (kapitoly o vývoji domu v 18.-19. století a o hospodářských stavbách), nebo se sepsání př́slušných kapitol ujali dva další architekti. Karel Kuča přispěl esejí o vývoji osídlení jižních Čech a Jan Pešta encyklopedickým přehledem regionálních okruhů lidové architektury 19. století. Peštova stostránková kapitola jako jediná není vytištěna, nýbrž je připojena na doprovodném CD spolu s kvalitně digitalizovanou původní knihou.

Jádro monografie tvoří rozsáhlý Škabradův výklad o klíčových problémových okruzích výzkumu vesnické architektury. Co se týče koncepce, nejvýraznější obměna, díky níž se zpřehlednila pojednávaná látka, spočívá v oddělní výkladu o vývoji domů a hospodářských staveb od typologicky pojatého nástinu jednotlivých druhů konstrukcí. Tím se v aktuální syntéze, částečně inspirované žánrem vysokoškolských skript, zřetelně projevují Škabradovy pedagogické zkušenosti, jichž nabýval po roce 1989. Za normalizace kariérně stagnoval, badatelsky ovšem nestrádal, ba naopak. V začátcích dráhy stavebního historika na něho mělo zásadní formativní vliv dlouhodobé působení ve Státním ústavu pro rekonstrukci památkových měst a objektů. Toto profesní ukotvení bylo nedocenitelné pro sběr studijního materiálu, což autor v úvodu nové knihy široce ozřejmuje. Z předpokladů rozvoje svého komparačně-analytického myšlení, v němž - nutno podotknout - vyniká jako málokdo, zdůrazňuje hlavně tehdejší zapojení do projektů tzv. inventarizace lidové architektury.

Za účelem plošných průzkumů celých regionů i jednotlivých vesnic objel stovky lokalit a vstoupil do interiérů bezpočtu staveb. Mapování prováděl v době, kdy byl oproti dnešku - jak zdůrazňuje mnohem snadnější př́stup do soukromých nemovitostí. Zároveň zmiňuje ještě jednu další podstatnou okolnost. Na vesnicích v normalizačních časech ještě existovalo relativně velké množství autenticky dochovaných obytných i hospodářských staveb, které byly bud' dlouhodobě neudržované, příp. se už rozpadaly. Proto se mu mnohokrát naskytla možnost zkoumat známky složitějšího vývoje a detailně poznat strukturu jednotlivých konstrukcí. Se zrychlenou stavební proměnou vesnic 
po roce 1989 takových př́ležitostí valem ubylo, at důsledkem demolic, nebo kvůli výrazným modernizačním přestavbám.

Vzhledem k neměnnosti diskurzivní povahy Škabradových textů v obou syntézách je jasné, že autor stále těží hlavně ze zkušeností, které učinil coby dvacátník a třicátník. Své dávné myšlenky nyní formuluje v zásadě stejně, nicméně mnohem košatěji a precizněji. $\mathrm{V}$ analyticky pojatém a přehledně členěném výkladu rozkrývá principy utváření celkové skladby zástavby vsí i jednotlivých hospodářských jednotek a poté probírá anatomii domu. Nejen archeologa zaujmou autorovy postřehy $\mathrm{k}$ tendencím $\mathrm{v}$ orientaci domů podle světových stran (z důvodu př́hodného oslunění), názorně demonstrované mj. na př́íkladu zástavby zaniklé středověké vsi Pfaffenschlag u Slavonic. Velký respekt vzbuzují vývojové analýzy mnoha př́íkladů fragmentace parcel a zmenšování návsí v důsledku zakládání chalupnických a domkářských nemovitostí. I v rámci této problematiky autor zmiňuje př́klad Pfaffenschlagu.

Jiři Škabrada na základě velkého množství dobře poznaných staveb z různých časových vrstev a několika regionů vytříbil už před delší dobou typologickou metodu, díky níž definoval hlavní stádia vývoje vertikální a horizontální skladby vesnických domů od pozdního středověku do 19. století. V první syntéze jsou tyto úvahy obsaženy v zárodečné fázi, v 80. letech teprve začínaly zrát v sérii článků (zvl. Škabrada 1986; 1987). Už tehdy ale získávaly pevné kontury, které jsou nyní argumentačně rozvedeny v jedné z klíčových kapitol, jednoduše nazvané Obytné stavby. Z hlediska archeologa je nejpodstatnější ta její část, jež se týká nejstaršího vývojového stádia, a sice domů s patrovou sýpkou v komorovém dílu. Škabradova perspektiva přitom není svázaná konvenčním periodizačním mezníkem oddělujícím středověk od raného novověku.

Mezi klíčové príḱlady, s nimiž autor operuje (v první i druhé syntéze), opět patří relikty staveb ze zaniklé středověké vsi Pfaffenschlag u Slavonic. Mezi nimi a dispozicemi nejstarších, uceleněji dochovaných jihočeských obytných staveb, jež pocházejí z 16.-17. století, neshledává podstatné rozdíly. Škabradova definice domu s patrovou sýpkou vychází z utváření zadního (komorového) dílu, obsahujícího ve spodní úrovni spížní komoru a nad ní sýpkové prostory. Toto horizontální členění se promítá nejen do podoby síně, ale i do dimenzí hlavní obytné místnosti, at měla formu jizby, nebo světnice. Ve středním dílu se víceúrovňové řešení komorového dílu projevuje existencí komunikačního uzlu, jehož součástí obvykle bývá schodištní sestup do spížní komory. Archeologové dnes pro tento útvar se samozřejmostí používají pojem šíje. Málokdo si však uvědomuje, že jej v širší známost kdysi uvedl právě Jiři Škabrada, a to na jihočeských příkladech, které se vyznačují masivním provedením postranních zídek (Škabrada 1978). Ještě zbývá dodat, že patrová forma komorového bloku se v obytné (vytápěné) místnosti projevuje výrazně zvýšeným stropem.

V první syntéze okrajově, nyní zásadním způsobem, je Škabradův výklad o genezi dispozice venkovského domu koncipován se zřetelem k principiálním proměnám systému otopných zařízení. Autor elegantně vysvětluje proces proměny jizby v dýmu prostou světnici a nastiňuje genezi černé kuchyně. Stejně názorně ukazuje, jak zásadně se změnil život v domě nástupem sporákủ, které nahradily kamna.

Kapitola Obytné stavby představuje v knize hlavní průsečík archeologie a stavební historie. Přínos archeologie je v této konfrontaci mnohem menší, ale nikoli nepodstatný. Do očí bijící je jiná skutečnost, a sice neměnný stav archeologických př́kladů, zapojených do textů otištěných v letech 1986 a 2021. Přitom autor opakovaně upozorňuje, že jeden z klíčových problémů, a to absolutní chronologie proměny jizby ve světnici, zůstává stále otevřen a jeho řešení závisí na archeologických zjištěních. Těch se ovšem dlouhodobě nedostává nejen v jižních Čechách, ale na celém území státu. Dosavadní výsledky záchranné archeologie ve vesnických jádrech příliš nadějí nevzbuzují. Případné odkryvy ve vybraných zaniklých vsích by proto bylo možné obhájit pádnými argumenty. Významná úloha, kterou v recenzované knize plní relikty domů ze zaniklého Pfaffenschlagu, k tomu přímo vybízí.

Dalším místem, kde v recenzované knize dostávají prostor archeologické poznatky, je jedna z úvodních kapitol nazvaná Sídelní vývoj jižních Čech. Jejím hlavním autorem je Karel Kuča, který se na šedesáti tiskových stranách pokusil vystihnout hlavní vývojové trendy osídlení od středověkých počátků po zásadní změny v 19. století. Už z absence poznámkového aparátu lze vytušit povrchnost výkladu. Autor na mnoha místech pateticky píše o svébytnosti jihočeského regionu, konkrétně ale 
neuvádí relevantní specifika, protože rezignuje na komparaci se sousedními českými či rakouskými regiony. Hlavní důraz je kladen na vývoj sídelních forem - intravilánů a plužin. Jednotlivé typy autor povšechně datuje podle chabě zdůvodněných předpokladů publikovaných před padesáti a více lety. Tím spíše zarazí, že v jihočeském kontextu nevyužil výjimečný soubor opor v podobě relativně vysokého počtu venkovských staveb dochovaných z konce středověku a samého počátku novověku. Pomocí nich mohl u řady lokalit důvěryhodně posuzovat stáří sídelní struktury, jak ji znázorňují první katastrální mapy z 19. století.

Do Kučova pojednání vstupuje formou několika medailonů Jiří Škabrada, který se na př́íkladech vybraných lokalit pokouší sledovat obecné vývojové trendy sídelních forem. Pro středověké období přitom využívá výsledky povrchových průzkumů, které v 70. letech minulého století realizoval a publikoval spolu se Zdeňkem Smetánkou. Na dvou př́kladech z rozhraní Strakonicka a Př́ibramska ukazuje posuny sídelních areálů v 12.-13. století. V kontextu dnešních nároků na pramennou kritiku ale tyto př́́klady neobstojí, protože v primární publikaci (Škabrada - Smetánka 1974) úplně schází zhodnocení keramických střepů, posbíraných na polích. S ohledem na pádné argumenty, jimiž byly zpochybněny Smetánkovy a Škabradovy závěry obdobně vyvozované z povrchových sběrů v jiné lokalitě (Ježek 2007, 534), ztrácejí důvěryhodnost i př́iklady ze Strakonicka. K dané problematice snesli archeologové v jižních Čechách mnohem relevantnější poznatky, řádně publikované v několika článcích v pozdější době (např. Ernée - Vařeka - Zavřel 1997). Tento dílčí pokrok archeologie není v recenzované syntéze reflektován.

Poukazem na rozvoj dendrochronologie Jiří Škabrada zdůvodňuje, proč v nové monografii chybí kapitola Nejstarší objekty, která představuje jeden z hlavních „stavebních kamenů“ původní syntézy. Autor v ní souhrnně pojednal dochované stavby předbělohorského stáří, přičemž koncepce výkladu vychází ze snahy zdůvodnit takto časnou dataci staveb na základě výskytu gotických a renesančních architektonických detailů. V době vzniku první knihy se ještě ozývaly pochybovačné hlasy o autenticitě použití gotických tesaných prvků v architektuře poddanských usedlostí, což byl hlavní důvod Škabradovy zevrubné argumentace k datování. Nezpochybnitelné doklady autor shromáždil (zprvu opět v tandemu se Zdeňkem Smetánkou: Škabrada - Smetánka 1978) z několika jihočeských regionů, kvalitou i kvantitou mezi nimi dodnes vyčnívají nálezy z poměrně malého území zvaného Kouty, které leží na pomezí Českobudějovicka a Českokrumlovska. Př́́klady staveb s gotickými a renesančními prvky se v hojné míře objevují i v nové knize, jsou v ní ale rozptýleny, a proto nevyniknou některé podstatné aspekty jejich výpovědní hodnoty.

Zvláště v oblasti zvané Kouty dokážeme sledovat celkové dispozice usedlostí, a to přinejmenším do 16. století. Soubor zdejších staveb s renesančními a gotickými prvky nemá v tomto ohledu obdobu v měřítku celých Čech, snad jen s výjimkou západního Sedlčanska. Je proto z podivem, že tato skutečnost není v nové knize náležitě zdůrazněna (alespoň na př́kladu nejdůkladněji poznaného areálu usedlosti čp. 1 v Krníně: Pešta 1997). Ještě více zarazí, že doklady výstavných obytných a hospodářských budov předbělohorského stáří autor pominul v kapitole nazvané Sociální členění zástavby. Křiklavější ukázky nadprůměrně bohatých poddanských statků si lze jen těžko představit. Z hlediska humanitních věd mimořádně zajímavé téma, jakým jsou právě architektonické projevy prezentace společenského postavení zámožných vesničanů z řad poddaných, ostatně Jiř́ Škabrada ponechává zcela stranou své pozornosti. Přitom právě oblast zvaná Kouty se stala předmětem metodicky pozoruhodné studie, zabývající se otázkou, do jaké míry zdejší drobné vsi s obrovskými statky představují výjimečný sídelní model (Ernée - Stejskal 2001). Reflexe tohoto zásadního př́íspěvku k poznání sociálního kontextu velkých poddanských statků v recenzované knize z nepochopitelných důvodů chybí. Tím zřetelněji vyniknou tematické limity syntézy o lidové architektuře, v jejímž autorském kolektivu jsou v podstatě výhradně zastoupeni architekti. V důsledku této skutečnosti je problematika řešená v kapitole Sociální členění zástavby redukována pouze na aspekty, jež ve venkovském prostředí poněkud nepatřičně zahrnujeme pod pojem urbanismus.

Mezi syntézami z let 1986 a 2021 shledáváme nejen koncepční rozdíly, markantních změn doznal i obrazový doprovod, byt' se v něm znovu skví výtečné Škabradovy fotografie. V nové knize se zhruba z poloviny uplatňují kresby a fotografie uveřejněné už v roce 1986. Je to pochopitelné i z toho důvodu, že předmět dokumentace často zanikl, nebo byl přetvořen výraznými adaptacemi. 
Přitom se jednalo o stavby mimořádně instruktivní pro poznání obecných vývojových tendencí. V nové knize se výrazně zvýšil počet reprodukcí historických stavebních plánů a map. Za tímto nárůstem důležitého pramenného materiálu stojí hlavně Škabradova spolupráce s archivářem Martinem Ebelem. Vítané oživení představují i kresby a fotografie z archivu Etnologického ústavu AV ČR, které pocházejí z tzv. zaměřovacích akcí realizovaných během druhé světové války. Dále přibyla řada cenných fotografií, které Jiř̌ Škabrada v jižních Čechách pořizoval př̀i různých př́ležitostech v uplynulých bezmála čtyřiceti letech. Kreseb po tuto dlouhou dobu pořídil jen minimum. Důvod této obrovské disproporce samozřejmě tkví v časové náročnosti. Hlavním zdrojem plánového doprovodu nové knihy jsou tak stále záznamy ze 70. a 80. let minulého století, což vyvolává nejvážnější výhradu vůči aktuální syntéze.

Vzhledem k nezadržitelnému úbytku autentických památek by bylo žádoucí, aby se terénní výzkum lidové architektury (nejen) v jižních Čechách rozvíjel řádově rychlejším tempem než dosud. Řádně publikovaných průzkumů důležitých staveb je stále málo, nicméně existují a v posledních letech přece jen přibývají v relativně vyšším počtu. Respekt a naději vzbuzují hlavně články badatelů z českobudějovického pracoviště Národního památkového ústavu. Tyto př́spěvky jsou v recenzované monografii citovány v textech Jiř́ho Škabrady, ale alibistickým způsobem: autor zveřejněné poznatky doslova ignoruje, přestože se namnoze týkají staveb, o nichž se blíže zmiňuje.

Nejmarkantnějším příkladem Škabradova problematického př́istupu je velká hospodářská budova středověkého stáří v selské usedlosti v Radošovicích u Strakonic. V aktuální syntéze je jí věnováno několik odstavců, které autor vyplnil hlavně vzpomínkami, kterak spolu se Zdeňkem Smetánkou před více než čtyřiceti lety objevil ve zdivu jejího štítu soubor zazděných keramických střepů, pomocí nichž se pokusili stavbu datovat. Komplexního průzkumu se daná budova, která se mezitím proměnila v ruinu, ale dočkala až nedávno. Podařilo se získat několik dendrodat a zachytit řadu nálezových situací svědčících o složitém stavebním vývoji, který započal v polovině 15 . století (Šnejd - Hansová 2016). Nyní je k dispozici i zaměření půdorysů, které předtím citelně scházelo. V porovnání s těmito výsledky představují střepy zazděné ve štítě nález marginálního významu. Škabradovo mlčení k poznatkům komplexního průzkumu, na kterém se nepodílel, proto sotva může mít racionální pohnutky.

V knize jsou ignorována dokonce i zevrubně publikovaná zjištění z hloubkového průzkumu vůbec nejstarší dochované stavby z rolnického prostředí v Čechách. Tato nálepka patřila domu selského gruntu v Mirkovicích u Českého Krumlova, jehož jádro pocházelo z 20. let 15. století. Dům, ač zanesený do seznamu státem chráněných památek, byl v roce 2013 demolován, přičemž zachránit se podařilo pouze jeho nejstarší část v podobě srubu obytné místnosti (dnes je uložen v rozebraném stavu v depozitáŕi muzea v Klatovech). Průzkum proběhl během demolice, proto se podařilo dokumentovat velké množství konstrukčních detailů (Havlice - Kodýdek - Šnejd 2014). Důvod, proč je tento mimořádný doklad středověké venkovské zástavby zmíněn v recenzované syntéze jen na okraj, Jiř̌ Škabrada aktuálně neobjasňuje. Na jiném místě ovšem svůj názor na publikaci průzkumu domu v Mirkovicích vyjádřil bez okolků: „Přes snahu o dokumentaci a průzkum stavby před její demolicí nejsou získané informace o této obytné místnosti i domu jako celku takové, aby umožnily srovnávací zapojení do souboru dalších nejstarších vesnických domů z našeho území. V naší práci tedy poznatky o tomto domě nepoužíváme“ (Škabrada 2018, 62). Zdůvodnění rezervovaného postoje ale působí podivně: článek o mirkovickém domě je vybaven standardní dokumentací a vyšel v časopise Průzkumy památek, v jehož redakční radě Jiř́ Škabrada zasedá. Pokud tedy chová výhrady ke způsobu publikování průzkumů jihočeských badatelů, měl by je v zájmu zdravého rozvoje oboru konkretizovat, aby se závadám mohlo předcházet.

Do závěrečného hodnocení recenzované monografie se vkrádá otázka, nakolik její hlavní autor dostál žánru syntézy. Jednou rovinou tohoto problému je výše nastíněné ignorování důležitých publikovaných výsledků dalších badatelů. Druhou rovinou je tematické vymezení. Čerstvá kniha jasně pokračuje v metodologické linii, od níž se Jiří Škabrada nikdy neodchýlil. V úvodu recenzované monografie tuto skutečnost vyjadřuje pregnantně: „Př́nos původní knihy, připravené dvěma architekty, vycházel z tehdy nového pohledu na lidovou architekturu jako součást obecného vývoje stavebního umění. Tento způsob nazírání se od té doby nepochybně dále osvědčoval, protože př̀nášel 
a přináší množství nových poznatků i vysvětlení skutečností, které se při odlišném pojetí vysvětlit nedaly. V tomto přístupu se i v nové edici snažíme pokračovat, jak je zřejmé také ze stále převažujícího zastoupení profese architekta v novém autorském kolektivu“"(s. 12-13).

Jestliže autor pochvalně hodnotí dobrovolnou izolaci vlastního oboru, je třeba mu důrazně namítnout, že určité vědní obory, které by bylo nanejvýš žádoucí vtáhnout do výzkumu vesnické architektury, učinily od 80 . let minulého století obrovský pokrok. V prvé řadě to platí pro sociálně zaměřenou historii. Jeden př́klad za všechny: jestliže je v recenzované monografii věnován velký prostor fenoménu zahuštování zástavby vsí v 18. a 19. století, novou a velkou dynamiku by stavební historie nabrala, pokud by reflektovala soudobou literaturu o populačních a sociálních změnách venkovského obyvatelstva v daném období. Hojnost podnětných studií je v tomto směru k dispozici právě pro jižní Čechy (např. Grulich 2009). V porovnání se soudobým pokrokem na poli historie se hned vyjeví diletantský ráz Kučova úvodního eseje. Obrátíme-li pozornost k archeologii, její vyhlídky na mezioborovou spolupráci při výzkumu architektury zemědělských usedlostí a sídelní struktury vesnic jsou neradostné. Z hlediska řešení určitých témat asi nezbývá, než aby se rozeběhly výzkumy zaniklých vesnic.

Jan Kypta

\section{Literatura}

Ernée, M. - Stejskal, A. 2001: Kouty na Českokrumlovsku. Běžný či výjimečný model vrcholně a pozdně středověkého osídlení?. Archeologické rozhledy 53, 310-342.

Ernée, M. - Vařeka, P. - Zavřel, P. 1997: Nové doklady osídlení 13. století na Českokrumlovsku. Archeologické výzkumy v jižních Čechách 10, 41-57.

Grulich, J. 2009: Populační vývoj a životní cyklus venkovského obyvatelstva na jihu Čech v 16. až 18. století. České Budějovice: Jihočeská univerzita.

Havlice, J. - Kodýdek, L. - Šnejd, D. 2014: Středověké jádro domu zemědělské usedlosti čp. 1 v Mirkovicích. Výsledky hloubkového průzkumu. Průzkumy památek 21/2, 139-155.

Ježek, M. 2007: Jaroměřsko v raném středověku. Archeologické rozhledy 59, 523-570.

Pešta, J. 1997: Usedlost čp. 1 v Krníně. Průzkumy památek 4/2, 101-115.

Škabrada, J. 1978: Sýpky domů v Pfaffenschlagu ve světle struktury vesnického domu jihočeské oblasti („Š́ije" vesnických sýpek a středověkých zemnic). Archaeologia historica 3, 355-369.

Škabrada, J. 1986: Základní rysy prostorové a konstrukční struktury domu zemědělské usedlosti pozdního středověku v Čechách. Archaeologia historica 11, 395-407.

Škabrada, J. 1987: Poznámky k pokračujícímu průzkumu domu čp. 2 v Lučici (Ke vzniku středověkého domu s trojdílným půdorysem). Archaeologia historica 12, 203-213.

Škabrada, J. 2018: Základní rysy typologie výstavby vesnických domů 16. a 17. století. In: J. Škabrada Z. Syrová-Anýžová edd., Nejstarší venkovské domy ve východních Čechách, Pardubice - Brno: Univerzita Pardubice - Společnost pro obnovu vesnice a malého města, 17-63.

Škabrada, J. - Smetánka, Z. 1974: K metodice povrchového průzkumu raně středověké vesnice. Památková péče 5, 297-306.

Škabrada, J. - Smetánka, Z. 1978: Architektura zemědělských usedlostí pozdního středověku v Čechách (Příspěvek k poznání hmotné kultury stř̌edověké vesnice). Archeologické rozhledy 26, 236-270.

Šnejd, D. - Hansová, J. 2016: Sýpka usedlosti čp. 9 v Radošovicích. Průzkumy památek 23/2, 93-102.

Voděra, S. - Škabrada, J. 1986: Lidová architektura v jižních Čechách. České Budějovice: Jihočeské nakladatelství. 
Ladislav Čapek - Rudolf Procházka - Lenka Sedláčková (eds.): Trojí život středověké keramiky. Katalog k výstavě. Západočeská univerzita v Plzni, Plzeň-Brno 2021. ISBN 978-80-216-1009-5. 161 str.

Jedním z výstupů projektu NAKI „Vrcholně středověká keramika jako součást movitého kulturního dědictví“ je velmi obsažný katalog ke stejnojmenné výstavě. Osm autorů textů, spolu s autory fotografií, modelů a dalšími tvůrci publikace, předložili široké veřejnosti poznatky o středověké keramice z 13. až 15. století. Je třeba podotknout, že se jedná především o kuchyňskou a stolní keramiku, takže kamnářské, stavební, technické a výtvarné produkci nebyla $v$ této souvislosti věnována větší pozornost.

Kateřina Těsnohlídková a Karel Slavíček se zaměřili na keramiku jako na výrobek z hlediska př́pravy materiálu, techniky formování i výpalu. $Z$ hlediska provenience se jeví jako velmi př́nosná metodika analýzy složení materiálu, z něhož byla keramika vyráběna, jak se ukázalo na dalším výstupu tohoto projektu (Slavíček - Petř́k - Španihel 2020). Pro poznání výpalu využili autoři experimenty, jejichž př́kladem je dobře fotograficky dokumentovaný výpal zakuřované keramiky (obr. 14). Lenka Sedláčková je autorkou kapitoly „Keramika jako nepostradatelná součást středověké měšt’anské domácnosti. V třetí kapitole se Lenka Sedláčková, Zdeňka Měchurová a Tereza Zemancová zabývají keramikou jako archeologickým pramenem. Popisují způsob terénního výzkumu, laboratorní ošetření, muzejní evidenci i možnosti vědeckého zpracování.

Jádrem katalogu je čtvrtá kapitola „Proměny středověké keramické produkce na př́kladu měst Brna, Jihlavy, Českých Budějovic a Plzně“. Lenka Sedláčková popsala základní proměny keramické produkce v Brně, které odráží charakteristiku celé jižní Moravy, navazující na domácí tradice, ale od 13. stol. ovlivněné vztahy s Podunajím, jejichž projevem jsou konvice s třmenovým uchem, ploché pokličky i další tvary. U tzv. nálevek, tj. tvarů bez dna, je uvedeno, že „funkci v brněnských domácnostech se prozatím nepodařilo jednoznačně určit" (str. 49). Podobně neurčitě jsou interpretovány keramické tvary, „,které archeologové nazývají nálevky či násypny (u nichž) se nepodařilo jejich funkci zcela osvětlit a již tradičně jsou spojovány se zpracováním mléka a výrobou tvarohu či sýrů“ (str. 20). Ludvík Belcredi navrhl název filtrační nádoba, který lépe vyjadřuje funkci doloženou i stopami po přivázání plátna na spodní okraj (Belcredi 2006, 332). Jiné využití těchto keramických tvarů nebylo zatím nabídnuto, takže by bylo možné se těšit na experimentální ověření, které by jistě nebylo př́iliš složité. $\mathrm{K}$ materiálu, $\mathrm{z}$ něhož byla keramika zhotovována, lze dodat, že ještě ve druhé třetině 13 . stol. se na jižní Moravě u keramiky používala tuha, která se v dalším století přidávala jen do materiálu pro zásobnice. Zatím nepř́liš známým je poznatek, že „V období druhé poloviny 14. století a první poloviny 15 . století byla do Brna dovážena keramika $\mathrm{s}$ kovově lesklým povrchem snad z oblasti Boskovicka a Blanenska“ (str. 54), což je dokumentováno i na obr. 51. Tak jako u produkce z dalších měst, je tvarová proměna středověké keramiky z 13. až počátku 16. stol. znázorněna na přehledné tabulce.

Proměny stř̌edověké keramické produkce $\mathrm{v}$ Jihlavě zpracovali Kateřina Těsnohlídková a David Zimola. Dvě archeologicky zkoumané pece z přelomu 13. a 14. stol. doložily, že ve stejné době se keramika vypalovala v konstrukčně různých pecích. Hlavní trendy keramické produkce, stejně jako na Brněnsku, směřovaly od keramiky grafitové ke keramice ostřené pískem. Některé tvary, jako koflíky nebo trojboké korbely, představují jihlavské specifikum.

Českobudějovickou středověkou keramiku představil na základě řady dřívějších studií Ladislav Čapek. Také zde byla grafitová keramika od přelomu 13. a 14. stol. nahrazována keramikou s př́měsí zrn hornin i slídy. Od poloviny 14. stol. je charakteristická radélková výzdoba v kombinaci geometrických tvarů a gotického písma.

Keramickou produkci z Plzně popsal Jiř́ Orna. Od 14. stol. i zde převládla režná redukčně vypálená keramika s př́měsí písku, která byla v 15 . stol. vystřídána jemnějším zbožím s kovově lesklým povrchem. Od poloviny 14 . stol. jsou pro místní keramickou produkci charakteristické hrnce zdobené vícenásobnou vlnicí. Právě u těchto tvarů narazil autor na problematiku datování keramiky podle nálezů mincí. Osm takto zdobených nádob bylo s mincemi uloženo kolem roku 1460 , což autor vysvětluje využitím nádob vyřazených z provozu, nebo ještě pravděpodobněji existencí rodinných pokladniček. Datování nádob podle depotů mincí je problematické a dnes se př́liš nepoužívá, o čemž svědčí i skutečnost, že v seznamu literatury nejsou uvedeny ani katalogy nádob s mincemi z Čech i Moravy (Radoměrský - Richter 1976; Nekuda 1980). Při pochopení problematiky by však bylo škoda tento chronologický aspekt zcela ignorovat. Pro plzeňskou keramickou produkci jsou od poloviny 14. stol. charakteristické i poháry s okrajem modelovaným do podoby čtyřlístku, jejichž objem 
se často pohybuje okolo 0,5 litru (jeden žejdlík). Také v Plzni se od přelomu 14. a 15. stol. objevuje výzdoba tzv. nápisovými radélky a od poloviny 15. stol. keramika s kovově lesklým povrchem.

Obrázkový katalog obsahuje 112 kvalitních fotografií nádob, které vedle dalších, zobrazených přímo v textu, dávají dobrou představu o keramické produkci v daném městě či regionu.

Nedostatkem současné archeologické publicistiky je málo prací, které by shrnovaly stav poznání nejen o chronologicky definovaných obdobích, ale také o nadčasových tématech (zemědělství, opevnění, těžba atd.) pro kulturní veřejnost i odborníky se zájmem o problematiku přesahující jejich specializaci. Autorům katalogu se podařilo rozhodně víc než jen přiblížit poznání středověké keramiky široké veřejnosti, ale předložili současný stav poznání tohoto archeologického pramene, který je přínosem i pro mnoho archeologů a historiků. Pohledem na obr. 41 se můžeme přesvědčit, že katalog je zaměřen na keramiku v jihozápadní a jižní části České republiky. Mnoho nových poznatků pochází také z Hradce Králové, Olomouce a Opavy, takže i tato města by si zasloužila podobné zpracování keramické produkce.

Josef Unger

\section{Literatura}

Belcredi, L. 2006: Bystřec. O založení, životě a zániku středověké vsi. Brno.

Nekuda, R. 1980: Korpus středověké keramiky datované mincemi z Moravy a Slezska. Archaeologia historica 5, 385-450.

Radoměrský, P. - Richter, M. 1976: Korpus české středověké keramiky datované mincemi. Sborník Národního muzea, řada A, 28, 57-171.

Slavíček, K. - Petř́k, J. - Španihel, S. 2020: Archeometrické studium raně novověké keramiky ze severozápadního Slovenska (Žilina, Budatín a Lietava). Archaeologia historica 45/1, 405-428.

Rudolf Procházka - Adéla Balcárková - Miriam Nývltová Fišáková - Antonín Přichystal: Přerov, Horní náměstí č.p. 19, 20. Otázky prostorového vývoje lokality a možnosti poznání socioekonomického profilu jejích obyvatel v 9.-12. století. Archeologický ústav AV ČR, Brno. Brno 2020. ISBN 978-80-7524-039-2. 167 str. Přílohy: Jan Petř́k - Karel Slavíček: Petrografická analýza keramického předmětu z Horního náměstí č.p. 19 v Přerově; Matěj Kmošek: Analýza a konzervace nýtu z barevného kovu u lokality Přerov,
Horní náměstí č.p. 19; Martin Hložek: Rentgenfluorescenční analýzy raně středověkých kovových artefaktů z Přrerova, Horní náměstí č.p. 19.

Vyzbrojen znalostmi z vlastního výzkumu v Přerově na Horním náměstí (Procházka 2017), pustil se Rudolf Procházka s kolektivem do vyhodnocení dvou přerovských výzkumů blízkých parcel z let 1990 a 1998, vedených Jiřím Kohoutkem a jeho spolupracovníky. V úvodu, představujícím dokumentaci, ze které R. Procházka vycházel, se kriticky vyjádřil k metodice výzkumu i způsobu dokumentace. První etapu roku 1990 zhodnotil tak, že ,mimořádně hodnotná lokalita byla tedy poškozena nelegálním postupem stavebníka, následně pak neadekvátním způsobem zkoumána, takže přišla o značnou část vypovídací hodnoty“ (str. 10). Neadekvátním způsobem je míněna především skrývka po mechanických vrstvách. Druhá etapa roku 1998, kde odkrývání probíhalo po tzv. přirozených vrstvách, je charakterizována tak, že ,dokumentace, která se (patrně neúplně) dochovala pouze v nálezové zprávě, má $\mathrm{k}$ dokonalosti daleko ... Závěrečné vyhodnocení je ještě na horší úrovni než v nálezové zprávě výzkumu z roku 1990“ (str. 10). $\mathrm{K}$ tomu lze dodat, že způsob provedení každého výzkumu je třeba přizpůsobit okolnostem, k nimž patř̌́ časový limit, finanční prostředky a kvalifikace pracovníkủ. Ostatně každý terénní výzkum mohl být prováděn detailněji a k dokonalosti má daleko. $\mathrm{Z}$ tohoto hlediska bychom měli hodnotit dotyčný výzkum v Přerově.

Následuje rekonstrukce časoprostorového vývoje osídlení na zkoumané ploše č.p. 19. Není pochyb, že to byla náročná práce. Na plánovou dokumentaci navazuje subkapitola zabývající se vztahem nálezové situace a keramických celků i shrnutí. $\mathrm{Na}$ tř̌ech tabulkách jsou z dokumentačních formulářů vytaženy údaje o vrstvách, sídlištních jamách, otopných zařízeních a zdivu. Vedle čísla objektu a jeho umístění je zařazen stručný popis, dále základní stratigrafické údaje a zařazení do sídlištního horizontu.

Podobně je zpracována i rekonstrukce nálezové situace v ploše č.p. 20. Je škoda, že hlavní autor do tabulkového přehledu vrstev, sídlištních jam a zdí nezařadil ojedinělý hrob $\mathrm{H} 1$ se vztahem $\mathrm{k}$ vrstvám 116,120 a 137. U vrstvy 137 , zařazené do horizontu II (keramika mladší doby hradištní 1), měl být přinejmenším otazník. Dokumentované skutečnosti i dodatečně zařazené nálezy (soubor deseti výdutí hrnců jednoznačně stř̌edohradištních), vedly k závěru, že ,je dosti dobře možné, že hrob náleží ještě období 2. poloviny 9 . století s prípadným př̌sahem do století desátého“" (str. 42). Je to více než možné, 
protože nedaleko odtud byly v minulosti objeveny hroby ze střední doby hradištní. Na okraj lze poznamenat, že dislokace některých kostí, především pravého předloktí pod pánví a posun pravé kosti ramenní, svědčí o pohřbu do dutého prostoru, patrně dřevěné rakve. Podobně jako u zkoumané plochy č.p. 19 bychom očekávali celkový diagram stratigrafické situace. Ideální, ale patrně neuskutečnitelné, by bylo provázání stratigrafie obou zkoumaných ploch. V kapitole „Zástavba v soudobém kontextu" srovnal autor objev čtyř až pěti srubủ se situací v Čechách a Polsku.

Druhá část publikace je věnována hmotné kultuře. Nejčastějším nálezem byla keramika, takže jí je věnována adekvátní pozornost z hlediska materiálu, tvaru nádob, formování okrajů, výzdobných motivů i hrnčiřrských značek (u nichž nebyla sledována možná identita). Keramiku se podařilo rozčlenit do tři horizontů, přičemž svrchní horizont I představuje „,horizont sekundárně smíšených nálezových celkü“" (str. 81), takže z hlediska chronologie nemá význam. Horizont II, související se sruby, lze klást do časového intervalu mezi sklonkem 10. století a polovinou 11. století, horizont III je stratigraficky pod horizontem II a je datován do druhé poloviny 10 . století. Po srovnání popisu a kreseb lze si udělat představu o keramické náplni jednotlivých horizontů a její proměně v čase. Pozornost je věnována nádobám se zvýrazněným hrdlem a nádobám dvoukónickým, u nichž se uvažuje o polském vlivu, či prrímo o prítomnosti piastovských bojovníkủ. Jejich zastoupení je však mezi keramikou výrazně menšinové. Zhodnocena je kostěná a parohová industrie, včetně názorů na funkční rozdělení proplétáčků a šídel, nebo bruslí a hladidel. Přesleny, zhotovené z keramiky i hornin, jsou představeny v tabulkovém popisu i kresebné dokumentaci. Pro lepší orientaci by jistě přispěl v textu tabulky odkaz na př́slušný obrázek. S aktivitami v lokalitě souvisí travní kosa, pružinové (pérové) nůžky a ojedinělé kousky kovářské strusky.

Podle nálezů zviŕrecích kostí jsou patrné určité rozdíly v zastoupení doma chovaných zvírat ze staršího a mladšího horizontu, přičemž ve starším horizontu je více zastoupen tur před ovcí/kozou i prasetem, v mladším horizontu to bylo naopak. Tento jev není v práci explicitně vysvětlen, ale př̀i srovnání s výsledky z dalších lokalit se uvažuje o souvislosti většího zastoupení prasat $\mathrm{s}$ konzumačními zvyklostmi výše sociálně postavených obyvatel. K tomu lze dodat, že hovězí dobytek potřebuje prostor pro luční pastvu a zimní zásobení senem, kdežto prase se mohlo pást $\mathrm{v}$ lesích a na zimu být zásobeno produkty z lesa.
Z prostředků směny se našly dva křřžové denáry ražené v saských mincovnách mezi léty 985 a 1000. Pro olověný soudkovitý artefakt přeslenovitého tvaru se nabízí využití jako závažíčka. K osobním předmětům a vybavení domácnosti patří nože, hřebeny a tzv. brousky, u nichž bylo provedeno měření za účelem zjištění prítomnosti otěrů kovů. Na čtyřech z nich byly zjištěny stopy olova, stř́ibra a mosazi. Dále se našly součásti věder, přezek a šperků, k nimž patř́ korály z polodrahokamů i skla, skleněné kroužky, prsten a záušnice. Poměrně málo jsou zastoupena militaria a výstroj jezdce a koně (šipky, ostruhy, podkovy, postranice). Mezi předměty sloužící $\mathrm{k}$ zábavě je zařazena kostěná flétna, provrtaná záprstní kost tura domácího (snad astragal) ad. K stavebnímu kování patří skoby a hřebíky. Mezi funkčně obtížně určitelné předměty je zařazeno šest kamenných kotoučků o průměru 24-25 mm, z nichž trri jsou provrtané. U těchto artefaktů se př́mo nabízí funkční určení jako hracích kamenů pro dva hráče, jejichž kameny byly odlišeny právě provrtem. U kotoučků ze zlomků výdutí keramických nádob je pouze odkaz na podobné kousky interpretované jako hrací kameny. Tato interpretace je samožrejmě možná: obroušení hran patrné na některých exempláríích (obr. 55) je připodobňuje $\mathrm{k}$ tvarům považovaným někdy za hrnčírssé čepele, což je interpretace nevyhovující. Experimentální ověření by si zasloužila hypotéza o využití těchto předmětů jako škrabadel při opracování kůží.

Pátá kapitola obsahuje celkové vyhodnocení výpovědi nálezových situací o sociokulturním profilu lokality a zařazení do středoevropského kontextu. Počátky plošného osídlení spadají do pokročilého 10. století. Sídelní aktivity se výrazně projevují od přelomu 10. a 11. stol., kdy zde existovalo opevněné sídlo. Při srovnání se situací v Polsku a Čechách pak ,přerovský hrad 10.-11. století lze zařadit $\mathrm{k}$ těm centrům, kde nebyl vyčleněn zvláštní rezidenční okrsek místních představitelů vrcholu sociální pyramidy“ (str. 134), a ,zástavba pokročilého 11 . století plynule navázala na předchozí etapu“ (str. 135). Z tohoto hodnocení vyplývá, že výzkumy provedené v letech 1990 a 1998 přinesly i přes uvedené nedostatky - poznatky, které doplňují to, co bylo o lokalitě napsáno při vyhodnocení mladšího výzkumu (Procházka 2017).

Josef Unger

\section{Literatura}

Procházka, R. 2017: Hrad Přerov v raném středověku (9.-11. století) a počátky mladohradištní hmotné kultury. Brno. 
Jakub Sawicki: Dress Accessories from Prague, c. 1200 - c. 1800 . Catalog of finds. Institut of Archaeology of the Czech Academy of Science Yellow Point Publications, Prague - Wroctaw 2021. 342 str.

Referovaná publikace je do určité míry pendanten jiné autorovy knihy. Svou grafickou úpravou a částečně i koncepcí navazuje na katalog kovových oděvních komponent shromážděných př̀i archeologickém výzkumu vratislavského náměstí Nowy Targ (Sawicki 2017). Obě prezentované kolekce artefaktů se však vzájemně dosti liší. Vratislavská je chronologicky mnohem sevřenější, tvoří ji předměty z 12.-15. století, které se koncentrujî́ v rozpětí 13.-14. století. V nově vydaném přehledu jsou vedle středověkých početně stejně zastoupeny i výrobky z renesančního a barokního období. Přesah do novověku ale není hlavní příčina skutečnosti, že zdánlivě párové katalogy nejsou ekvivalentní.

Zatímco prezentace vratislavské kolekce představovala součást komplexní publikace terénního výzkumu, u pražské vyvstávají v tomto ohledu otazníky. Do aktuálně sestaveného vzorku dokladů oděvní kultury byly zahrnuty nálezy získané při 11 archeologických výzkumech, přičemž by bylo iluzorní si myslet, že většina z těchto akcí bude v dohledné době publikačně zúročena. Tento dluh se v katalogu markantně projevuje u datace, která u většiny položek obnáší rozpětí dvou či tř́ staletí. Př́ílušné výzkumy jsou v knize heslovitě charakterizovány, přičemž na každou akci připadají pouhé dvě strany. Autory tohoto bloku krátkých zpráv jsou T. Cymbalak, J. Havrda, K. Levá a J. Podliska, což dává tušit, že výzkumy byly provedeny pod hlavičkou instituce nazývané dnes Národní památkový ústav. Většinou se jedná o akce z posledního dvacetiletí.

Nálezové okolnosti prezentovaných artefaktů jsou značně pestré. Mnohé pocházejí z městských parcel, kde je můžeme označit jako náhodné ztráty. Specifický a početný soubor představují polotovary z areálu dílny specializující se na výrobu přezek. Opory pro definování sociálního kontextu zcela postrádáme u nálezů z močálu, který byl po staletí využíván jako obrovská komunální skládka odpadu. Př́íslušné výzkumy byly realizovány na území Malé Strany, Staré Města a Nového Města.

Gros knihy tvoří katalog čítající 743 položek. Hesla jsou přehledně strukturovaná, veškeré předměty jsou prezentovány kvalitními fotografiemi. Ze středověkých situací pocházejí hlavně komponenty opasků, zvláště přezky rozličných tvarů a různá kování ryze dekorativní funkce. Druhová škála novověkých výrobků je mnohem pestř̌jší. Početně výrazně jsou mezi nimi zastoupeny díly segmentových opasků, plechová zakončení tkanic, dále pak háčky a oka sloužící k zavěšování různých předmětů k pasu. Autor patří k předním znalcủm kovových oděvních komponent pozdního středověku a raného novověku, jeho funkčním klasifikacím lze proto plně důvěřovat a jím používanou terminologii bez obav přebírat. Katalog je formou exkurzu doprovozen zprávou E. Ottenwelter, která u vybraných výrobků analyzovala materiálové složení.

Vyhodnocení pražské kolekce oděvních komponent je oproti předchozímu katalogu pojato odlišně. Na vratislavském vzorku autor demonstroval hlavně výrobní postupy dávných řemeslníků. Tuto problematiku nyní vypustil, aby se neopakoval. Aktuálně svou pozornost upřel dvěma směry. Jednak se v tradičním duchu zaměřil na typologicko-chronologickou komparaci pražských nálezů v širokém geografickém rámci. A za druhé se pokouší uvést do středoevropského prostředí diskurz anglosaského a skandinávského bádání. Konkrétně má snahu interpretovat oděvní komponenty jako prostředky prezentace sociálního postavení dávných majitelů. Po vzoru jednoho čerstvého článku dvojice dánských archeologů nálezy tř́íí do několika kategorií, jimž přikládá určitý výpovědní potenciál. Díky statistickému hodnocení a neotřelé terminologii vyvolává autorův výklad zdání inovativní metody, při hlubším zamyšlení však vzbuzuje vážné pochybnosti.

V prvé řadě vyvstává otázka, do jaké míry se v daném souboru výrobků odráží pestré sociální složení obyvatelstva Prahy v pozdním středověku a raném novověku. $Z$ celého katalogu lze pouhou jednu položku charakterizovat prívlastkem luxusní: výzdobou a zhotovením ze stříbra vyčnívá stříbrná šatní spona. Statistické analýzy, jež ústí v sociotopografické závěry, proto autor rozvíjí na takových výrobcích z neželezných kovů, které nesou jednoduchou rytou či vytlačovanou výzdobu. Na tuto kategorii, která tvoři přibližně třetinu celé kolekce, paušálně nahlíží jako na výrazové prostředky sociálního postavení. Jen vágně ale definuje, které konkrétní vrstvy obyvatel pražského souměstí by se jejich nošením měly lišit od jiných. Bez vysvětlení obecně uvažuje, že výrobky z této kategorie fungovaly jako znamení sociálního postavení, „but rather within the lower classes" (s. 82). Odlišovaly snad řemeslníky od chudiny? Absurdní je, když autor na základě absolutního počtu takových výrobků hodnotí zámožnost obyvatelstva jednotlivých městských čtvrtí, aniž by přihlédl $\mathrm{k}$ bohaté literatuře historiků o sociální skladbě obyvatelstva 
pražských měst. Jestliže jeden archeologický výzkum poskytl dvacet jednoduše zdobených mosazných přezek a jiný jen třeba pět, tento rozdíl přece vůbec nic nevypovídá o zámožnosti držitelů daných parcel. Do nerovnoměrné distribuce nálezů se spíše promítají depoziční a postdepoziční procesy historických terénů, případně plošný rozsah výzkumů. Tyto obtížně postihnutelné faktory autor vůbec nebere v potaz.

Problematičnost autorova prímočarého statistického způsobu hodnocení kovových oděvních doplňků, které zařazuje do kategorie „,conspicious objects through funkcionality“ a interpretuje jako znaky „of social affiliation to a specific community“ (s. 78), lze názorně demonstrovat na př́íkladu výrobků, pro něž se v současné literatuře ujalo poněkud krkolomné označení: nákončí s liliovitým zakončením. Pocházejí ze 14.-15. století; v pražském katalogu jsou zastoupena pěti exempláríi. Že šlo o výrobky masové produkce a plošné distribuce, jasně ukazují nálezy tzv. detektorářù, přibývající geometrickou řadou. Výmluvný je jejich čerstvě publikovaný přehled z Chrudimska a Pardubicka (Musil 2020). Jen z katastru vsi Lhota pod Přeloučí je dosud známo 17 (!) těchto výrobků. Náhodně ztracená nákončí v polích a lesích nelze samozřejmě jednotlivě přiřadit příslušníkům konkrétních sociálních skupin, ale vzhledem $\mathrm{k}$ absolutním číslům není pochyb, že představovaly běžnou součást oděvní kultury poddanského obyvatelstva venkova. Jejich výpověd’ pro rekonstrukci sociální mapy pražského souměstí je proto nulová. Stejně tomu bude u všech dalších výrobků, které autor jen podle výzdoby vágně začleňuje do téže kategorie "conspicious objects through funkcionality“. Ostatně, ani koncentrace uvedených nákončí na Chrudimsku a Pardubicku není interpretačně relevantní, protože př́činně souvisí s nerovnoměrným stavem publikování pramenné základy, resp. mírou evidence nálezů tzv. detektorářu ze strany místních archeologů.

Referovaný katalog drobných kovových výrobků z Prahy vzbuzuje rozporuplné pocity. Je nepochybně cenným plodem specializovaného znalectví oděvní kultury pozdního středověku a raného novověku. Autorova snaha překročit tento úzký diskurzivní rámec ale ústí v ukvapené závěry, založené na premise, že v dekoru výrobků se může odrážet pestrá sociální skladba obyvatelstva jedné z nejvýznamnějších středoevropských metropolí. Nepochybně to platí v príípadě zlatých a stř́ibrných drahocenností, nikoli ovšem u sériově zhotovovaných výrobků z neušlechtilých kovů.

Při patřičně kritickém pohledu poskytuje kata$\log$ poučení o limitech výpovědních schopností archeologických nálezů, které nedokáže prolomit ani sofistikovaná analýza, natož prostá statistická komparace. Iluze archeologů by měl rozptýlit už sám fakt, že dohromady 11 terénních výzkumů přineslo jen jednu jedinou kovovou oděvní komponentu, kterou lze označit jako luxusní. Přitom se po pražských městech procházely stovky zámožných osob, v jejichž zevnějšku se nepochybně zračilo vyšší sociální postavení.

Jan Kypta

\section{Literatura}

Musil, J. 2020: Středověká nákončí s geometrickou rytou výzdobou z východočeské oblasti. In: I. Hlobil - M. Dospěl edd., Uprostřed Koruny české. Kolektivní monografie NAKI II, Prostějov: Oberon, 165-172.

Sawicki, J. 2017: Medieval dress accessories from Nowy Targ Square in Wrocław. Catalog of finds. Wrocław: Yellow Point Publications. 